\author{
Mehmet Akif Ersoy Üniversitesi Fen Bilimleri Enstitüsü Dergisi 12(1): 1-9 (2021) \\ The Journal of Graduate School of Natural and Applied Sciences of Mehmet Akif Ersoy University 12(1): 1-9 (2021)
}

Araştırma Makalesi / Research Paper

\title{
Muş İlindeki Besi İşletmelerinde Sürdürülebilir Üretim ve Bunu Etkileyen Faktörler
}

\author{
Galip BAKIR ${ }^{\mathbb{D} 1}$, Mustafa KIBAR ${ }^{\left(\mathbb{D} 2^{*}\right.}$ \\ ${ }^{1}$ Kahramanmaraş Sütçü İmam Üniversitesi, Ziraat Fakültesi, Kahramanmaraş \\ ${ }^{2}$ Selçuk Üniversitesi, Ziraat Fakültesi, Konya \\ Geliş Tarihi (Received): 28.06.2020, Kabul Tarihi (Accepted): 24.12.2020 \\ $\square$ Sorumlu Yazar (Corresponding author*): mustafakibar@siirt.edu.tr \\ (C) +903322232812 등 +903322410108
}

ÖZ

Bu çalışma Muş ili besi işletmelerinde sürdürülebilir üretim ve bunu etkileyen faktörlerin belirlenmesi amacıyla yürütülmüştür. Bu amaçla, Muş ili merkez ve ilçelerinde rastgele örnekleme yöntemi kullanılarak saptanan 368 işletmeci ile anket çalışması yapılmıştır. Yapılan araştırmada, işletmecilerin \%83,8'i besiciliği sürdürmek istediğini belirtirken \%16,2'si sürdürmek istemediğini bildirmiştir. Besiciliği sürdürme isteği ile yaş, eğitim seviyesi ve deneyim arasında pozitif ilişki, hayvan sayısı ile negatif ilişki tespit edilmiştir. Besiciliği baba mesleği ve severek yapan işletmecilerin, başka iş olmadığı için yapanlardan daha memnun oldukları ve işi sürdürmek istedikleri belirlenmiştir. Besi sonunda hayvanlarını eder fiyata satan işletmecilerin besicilikten memnun oldukları ve besiciliği de severek yaptıkları belirlenmiştir. Sonuç olarak, besiciliğin sürdürülebilirliğini, işletmecilerin yaşı, eğitim durumu ve deneyimleri ile mevcut hayvan sayısı, besi sonunda hayvanların eder fiyata satılması olumlu yönde etkilemektedir.

Anahtar Kelimeler: Besi işletmesi, etkili faktörler, Muş ili, sürdürülebilir üretim

\section{Sustainable Production and Affecting Factors in Fattening Farms of Muş Province, Turkey}

\begin{abstract}
This study was carried out in order to determine the sustainable production and the factors affecting this in the fattening farms of Muş province. For this purpose, a survey was conducted with 368 farmers determined by using random sampling method in the center and districts of Muş province. In the research, $83.8 \%$ of the farmers stated that they wanted to continue fattening, while $16.2 \%$ of them stated that they did not want to continue. A positive relationship was found between the desire to continue breeding and age, education level and experience, and a negative relationship with the number of animals in farms. It has been determined that the fattening farms and those who fondly do it are more satisfied than those who do it because there is no other job and they want to continue their business. It has been determined that the farmers who sell their animals at a fair price at the end of the fattening are satisfied with the fattening and love it. As a result, the sustainability of fattening, the age of the operators, educational status and experience, the number of animals available, and the sale of animals at a fair price at the end of fattening positively affect.
\end{abstract}

Keywords: Fattening farms, effective factors, Muş province, sustainable production 


\section{Giriş}

Son yıllarda sürdürülebilirlik kavramı toplumda önemli hale gelmiş ve gelecek kuşakların ihtiyaçlarını karşılamalarına engel olmadan bugünün ihtiyaçlarını karşılamak olarak tanımlanmıştır (Russell ve ark., 2007). Daha sonraki yıllarda ise sürdürülebilirlik bir kurumun veya işletmenin varlığını sürdürebilme kabiliyeti olarak algılanmaya başlamış ve kurumsal sürdürülebilirlik ön plana çıkmıştır (Hockerts, 2001). Sürdürülebilir tarım, uzun dönemde doğal kaynakların korunmasının yanı sıra çevreye zarar vermeyen tarımsal teknolojilerin kullanıldığı bir tarımsal yapının oluşturulmasıdır. Türkiye'de, tarım tamamen endüstriyel karakter kazanmamakla birlikte dünyanın gelişmiş ülkelerinde olduğu gibi, bir yandan sentetik üretim girdileri denetimsizce kullanılmakta, diğer yandan da günümüzde olumsuz işleme teknik ve teknolojilerin oluşturdukları sonuçları düşünmeden oldukça yoğun bir tarımsal üretim yapılmaktadır. Günümüzde bu uygulamaların doğal dengenin bozulmasına olan etkileri ve besin zinciri yoluyla insanın yanı sıra tüm canlılara ulaşabilen yaşamsal tehlike yaratma özellikleri de sanayi ya da kentsel kirlilikler kadar dikkat çekmeye başlamıştır (Turhan, 2005; Pezikoğlu, 2012). Sürdürülebilir ve ekonomik bir besi sığırcılığı için hayvanların genetik kapasitesinden fizyolojik sınırlar içerisinde ve uygun çevre şartlarında maksimum yararlanmak gerekmektedir. Bu nedenle Türkiye'de mevcut durumda, çeşitli nedenlerden dolayı sürdürülebilir besi sığırcılığı işletmelerinin sayısının yeterli olmadığı ve bu işletmelerin sayısının artırılması için maliyetlerin düşürülmesi ve fiyat istikrarı gibi önlemlerin alınması gerekmektedir (Bakır ve Kibar, 2019a).

Muş ilinde tarımsal faaliyetlere mevsim sınırlayıcı etken olurken, temel ekonomik sektörler içerisinde hayvancılık önemli bir yer tutmaktadır. Çayır ve meraların fazla olması sığırcılık için önemli bir alan açmaktadır. Muş il genelinde 126.540 baş melez, 104.698 baş yerli, 68.280 baş kültür ve 6.990 baş manda bulunmaktadır. Büyükbaş hayvan dağılımı içerisinde kültür ırklarının oranı Muş ili ve Türkiye'de sırasıyla \%22,28 ve \%48,46 şeklindedir. Buna göre, Muş genelinde kültür ırklarının hala yeteri kadar yaygınlaşmadığı anlaşılmaktadır. İnek başına yıllık ortalama süt verimi kültür ırklarında 3,5 ton, melez ırklarda 2,7 ton, yerli ırklarda 1,4 ton olup ortalama 2,33 ton olarak belirlenmiştir (Anonim, 2018). Muş ilindeki besi işletmelerinde ortalama hayvan sayısı 41,72 baş iken süt işletmelerinde 37,54 baş olarak tespit edilmiştir. Hem besi hem de süt işletmelerinde melez ırklar içerisinde Simental ve Esmer melezleri daha çok tercih edilmektedir. Her iki işletme tipinde de karşılaşılan sorunların veteriner hizmetinin pahalı olması, destek primlerinin az olması ve yemin pahalı olması olduğu bildirilmiştir (Bakır ve Kibar, 2019c; Bakır ve Kibar, 2020).
Hayvancılık işletmelerinin yapısal özelliklerinin belirlenmesine yönelik yapılmış bazı araştırmalar (Öztürk, 2009; Şeker ve ark., 2012; Köseman ve Şeker, 2016) bulunmasına rağmen; sürdürülebilirliğine yönelik şu ana kadar yapılmış ve tarafımızdan belirlenen araştırmalar son derece sınırlıdır (Soyak ve ark., 2007; Koçyiğit ve ark., 2016; Bakır ve Kibar, 2019a). Muş ilindeki büyükbaş süt sığırı işletmelerinde Bakır ve Kibar (2019a) tarafından yapılan bir araştırmada, işletmecilerin \%88,9'unun hayvancılığı sürdürmek istedikleri ve sürdürme nedeni olarak; işletmecilerin \%43,3'ünün başka işlerinin olmadığı, \% 20,1'inin hayvancılığı karlı bulduğu, \%18,5'inin elde ettiği gelirin kendilerine yettiği, \%9,4'ünün hayvancılığı sevdikleri ve \%8,7'sinin ise bu sebeplerin ikili veya üçlü kombinasyonlarından oluşan diğer nedenlerden kaynaklandığı bildirilmektedir. Soyak ve ark. (2007) Tekirdağ ilinde yaptıkları çalışmada işletmelerin \%47'sinin hayvancılığı sürdürmek istediklerini; Koçyiğit ve ark. (2016) işletmecilerin \%87'sinin sığırcılığı sürdürmek istedikleri ve sürdürme nedeni olarak, yapacakları başka işlerinin olmamasını $(\% 37,9)$, elde edilen gelirin yeterli olmasını (\%26,4), besiciliği sevdiklerini $(\% 20,7)$ ve besiciliğin karlı olduğunu $(\% 14,9)$ belirtmişlerdir. Besi işletmelerinde sürdürülebilirlik üzerine yeterli çalışma yapılmadığı için bu araştırmanın, alandaki açığı kapatmaya ve literatüre katkı sağlamaya katkı yapacağı düşünülmektedir.

Bu çalışmanın amacı, Muş ili besi sığırcılığı işletmelerinde, sürdürülebilir üretim ve bunu etkileyen faktörlerin belirlenmesidir.

\section{MATERYAL VE YÖNTEM}

Araştırma materyalini, Muş ili merkez ve ilçelerinde (Malazgirt, Bulanık, Hasköy, Korkut ve Varto) bulunan büyükbaş besi işletmelerinin sahipleriyle 2017 yılında yüz yüze yapılan anketlerden elde edilen veriler oluşturmuştur. Muş İ Tarım ve Orman Müdürlüğü kayıtlarından alınan toplam işletme sayısı (2000) dikkate alınarak, 368 $(\% 18,4)$ işletme şansa bağlı olarak belirlenmiştir. Muş ilinin mevcut şartlarından dolayı işletme büyüklükleri dikkate alınmamış ve ulaşılabilen işletmelerde anket çalışması yürütülmüştür. İşletme sayısının belirlenmesinde ise örnek hacminin en az \%3'ünün (Yamane, 2006) veya en çok örnek hacminin \%10'unun (Cochran, 1977) alınmasının yeterli olacağı ilkesi dikkate alınmıştır. Anketler çalışmanın sahipleri ve Muş II Tarım ve Orman Müdürlüğü personelleri tarafından işletmeler tek tek ziyaret edilerek yapılmıştır. İşletmenin ziyaret zamanları personellerin aşı vb. programlarına göre düzenlenmiştir. Verilerin analizinde SPSS 21.0 paket programı kullanılmıştır (SPSS Inc., 1999). İlçeler arasındaki farklılıkların belirlenmesi için ki-kare önemlilik testinden yararlanılmıştır (Düzgüneş ve ark., 1983). 


\section{BULGULAR VE TARTIŞMA}

Yapılan araştırmada, ilçelerle besiciliğin sürdürülmesi arasındaki ilişki Tablo 1'de sunulmuştur.

Tablo 1. Besiciliğin ilçelere göre sürdürülebilirliği

\begin{tabular}{|c|c|c|c|c|c|c|c|c|c|c|c|c|c|}
\hline \multirow[b]{2}{*}{ İlçe } & & \multicolumn{2}{|c|}{$\begin{array}{l}\text { Sürdürmeyi } \\
\text { isteme* }\end{array}$} & \multirow[b]{2}{*}{ Toplam } & \multicolumn{4}{|c|}{ Sürdürme nedeni** } & \multirow[b]{2}{*}{ Toplam } & \multicolumn{3}{|c|}{ Sürdürmeme nedeni** } & \multirow[b]{2}{*}{ Toplam } \\
\hline & & Evet & Hayır & & Karlı & Yetiyor & $\begin{array}{l}\text { Başka } \\
\text { iş yok }\end{array}$ & Sevmek & & $\begin{array}{l}\text { Karlı } \\
\text { değil }\end{array}$ & $\begin{array}{r}\text { Zamanı } \\
\text { yok }\end{array}$ & Sevmiyor & \\
\hline \multirow{2}{*}{ Merkez } & Adet & 48 & 11 & 59 & 1 & 6 & 33 & 8 & 48 & 7 & 4 & 0 & 11 \\
\hline & $\%$ & 81,4 & 18,6 & 100,0 & 2,1 & 12,5 & 68,8 & 16,7 & 100,0 & 63,6 & 36,4 & 0,0 & 100,0 \\
\hline \multirow{2}{*}{ Malazgirt } & Adet & 66 & 10 & 76 & 11 & 28 & 23 & 4 & 66 & 7 & 3 & 0 & 10 \\
\hline & $\%$ & 86,8 & 13,2 & 100,0 & 16,7 & 42,4 & 34,8 & 6,1 & 100,0 & 70,0 & 30,0 & 0,0 & 100,0 \\
\hline \multirow{2}{*}{ Bulanık } & Adet & 77 & 10 & 87 & 14 & 11 & 40 & 12 & 77 & 7 & 2 & 1 & 10 \\
\hline & $\%$ & 88,5 & 11,5 & 100,0 & 18,2 & 14,3 & 51,9 & 15,6 & 100,0 & 70,0 & 20,0 & 10,0 & 100,0 \\
\hline \multirow[b]{2}{*}{ Hasköy } & Adet & 11 & 5 & 16 & 1 & 4 & 4 & 2 & 11 & 5 & 0 & 0 & 5 \\
\hline & $\%$ & 68,8 & 31,3 & 100,0 & 9,1 & 36,4 & 36,4 & 18,2 & 100,0 & 100,0 & 0,0 & 0,0 & 100,0 \\
\hline \multirow{2}{*}{ Korkut } & Adet & 52 & 18 & 70 & 19 & 17 & 12 & 4 & 52 & 2 & 8 & 8 & 18 \\
\hline & $\%$ & 74,3 & 25,7 & 100,0 & 36,5 & 32,7 & 23,1 & 7,7 & 100,0 & $11, \overline{1}$ & 44,4 & 44,4 & 100,0 \\
\hline \multirow{2}{*}{ Varto } & Adet & 51 & 5 & 56 & 24 & 14 & 12 & 1 & 51 & 2 & 2 & 1 & 5 \\
\hline & $\%$ & 91,1 & 8,9 & 100,0 & 47,1 & 27,5 & 23,5 & 2,0 & 100,0 & 40,0 & 40,0 & 20,0 & 100,0 \\
\hline \multirow{2}{*}{ Toplam } & Adet & 305 & 59 & 364 & 70 & 80 & 124 & 31 & 305 & 30 & 19 & 10 & 59 \\
\hline & $\%$ & 83,8 & 16,2 & 100,0 & 23,0 & 26,2 & 40,7 & 10,2 & 100,0 & 50,8 & 32,2 & 16,9 & 100,0 \\
\hline
\end{tabular}

${ }^{*} p<0.05,{ }^{* *} p<0.01$

Araştırmadan elde edilen bulgulara göre, işletmecilerin $\% 40,7$ 'si yapacak başka işleri olmadığı, \%26,2'si elde edilen gelirin kendilerine yettiği ve \%23'ü de karlı olduğu için besiciliği sürdürmeyi $(\% 83,8)$ istemektedir. Diğer yandan, işletmecilerin \%50,8'i karlı olmadığı, \%32,2'si zamanları olmadığı ve \%16,9'u ise sevmedikleri için besiciliği sürdürmeyi düşünmedikleri belirlenmiştir. İşletmelerin bulunduğu mevki ile besiciliği sürdürme $(p<0.05)$, sürdürme ve sürdürmeme nedenleri arasında önemli $(p<0.01)$ ilişkiler bulunmuştur. Buna göre, Merkez $(\% 68,8)$ ve Bulanık $(\% 51,9)$ ilçelerindeki işletmeciler yapacak başka işleri olmadığı için besiciliği sürdürmek istemektedirler. Mevkiler arasında en düşük sürdürmeyi isteme oranı \%68,8 ile Hasköy ilçesinde bulunmuştur. Bu ilçedeki besiciliği sürdürmek isteyen işletmecilerin tamamı besiciliği karlı bulmazken, sürdürmek isteyen işletmecilerin en fazla yapacak başka işleri olmaması ve elde edilen gelirin kendilerine yetmesi nedeniyle sürdürmek istedikleri belirlenmiştir. Malazgirt ilçesindeki işletmecilerin elde edilen gelirin kendilerine yetmesi $(\% 42,4)$, Korkut ve Varto ilçelerindeki işletmeciler ise besiciliği karlı buldukları $(\% 36,5, \% 47,1)$ için besiciliği sürdürmek istemektedirler. Varto ilçesinde işletmecilerin tamamına yakını işi sürdürmek isterken, bu oran Hasköy ilçesinde $\% 68,8$ oranı ile diğer ilçeler arasında en düşük olarak bulunmuştur. Hasköy'de işi sürdürmek istemeyen $(\% 31,2)$ işletmecilerin tamamı hayvancılığın karlı olmadığını bildirmişlerdir (Tablo 1). Genel olarak işletmecilerin besiciliği sürdürmemesinde, besiciliğin karlı olma- ması, sürdürmesinde ise yapacak başka işlerinin olmaması ve besicilikten elde edilen gelirin yetmesi etkili faktörler olarak ön plana çıkmaktadır.

Bu konuda yapılan benzer araştırmalarda, Soyak ve ark. (2007)'ı Tekirdağ ilindeki işletmelerin \%47'sinin hayvancılığı sürdürmek istediklerini belirtmişlerdir. Bakır ve Kibar (2019a) Muş ilindeki işletmecilerinin \%88,9'unun hayvancılığı sürdürmek istediklerini bildirmiştir. Aynı araştırmada sürdürme nedeni olarak, işletmecilerin yapacak başka işlerinin olmamasının $(\% 43,3)$ en yüksek paya sahip olduğu bildirilmiştir. Koçyiğit ve ark. (2016)'ı ise, Erzurum ili Hınıs ilçesindeki işletmecilerin \%87'sinin sığırcılığı sürdürmek istediğini ve sürdürme nedeni olarak da yapacak başka işlerinin olmamasının $(\% 37,9)$ en yüksek paya sahip olduğunu bildirmişlerdir. Bakır ve Kibar (2019b) Siirt ilindeki besi işletmecilerin \%87'sinin işlerini sürdürmek istediklerini ve sürdürme nedeni olarak yapacak başka işlerinin olmadığını $(\% 37,9)$, elde edilen gelirin yeterli olduğunu $(\% 26,4)$, besiciliği sevdiklerini $(\% 20,7)$ ve besiciliğin karlı olduğunu $(\% 14,9)$ belirtmişlerdir. Mevcut araştırmada bulunan hayvancılığı sürdürme oranı, Soyak (2007)'ın değerinden yüksek iken, Bakır ve Kibar (2019a), Bakır ve Kibar (2019b) ve Koçyiğit ve ark. (2016)'nın değerlerinden düşük bulunmuştur.

Yapılan araştırmada, yetiştiricilerin sosyo-demografik yapıları ile besiciliğin sürdürülmesi arasındaki ilişki Tablo 2'de sunulmuştur. 
Muş İlindeki Besi İşletmelerinde Sürdürülebilir Üretim ve Bunu Etkileyen Faktörler

Tablo 2. Yetiştiricilerin sosyo-demografik yapıları ile besiciliğin sürdürülmesi arasındaki ilişki

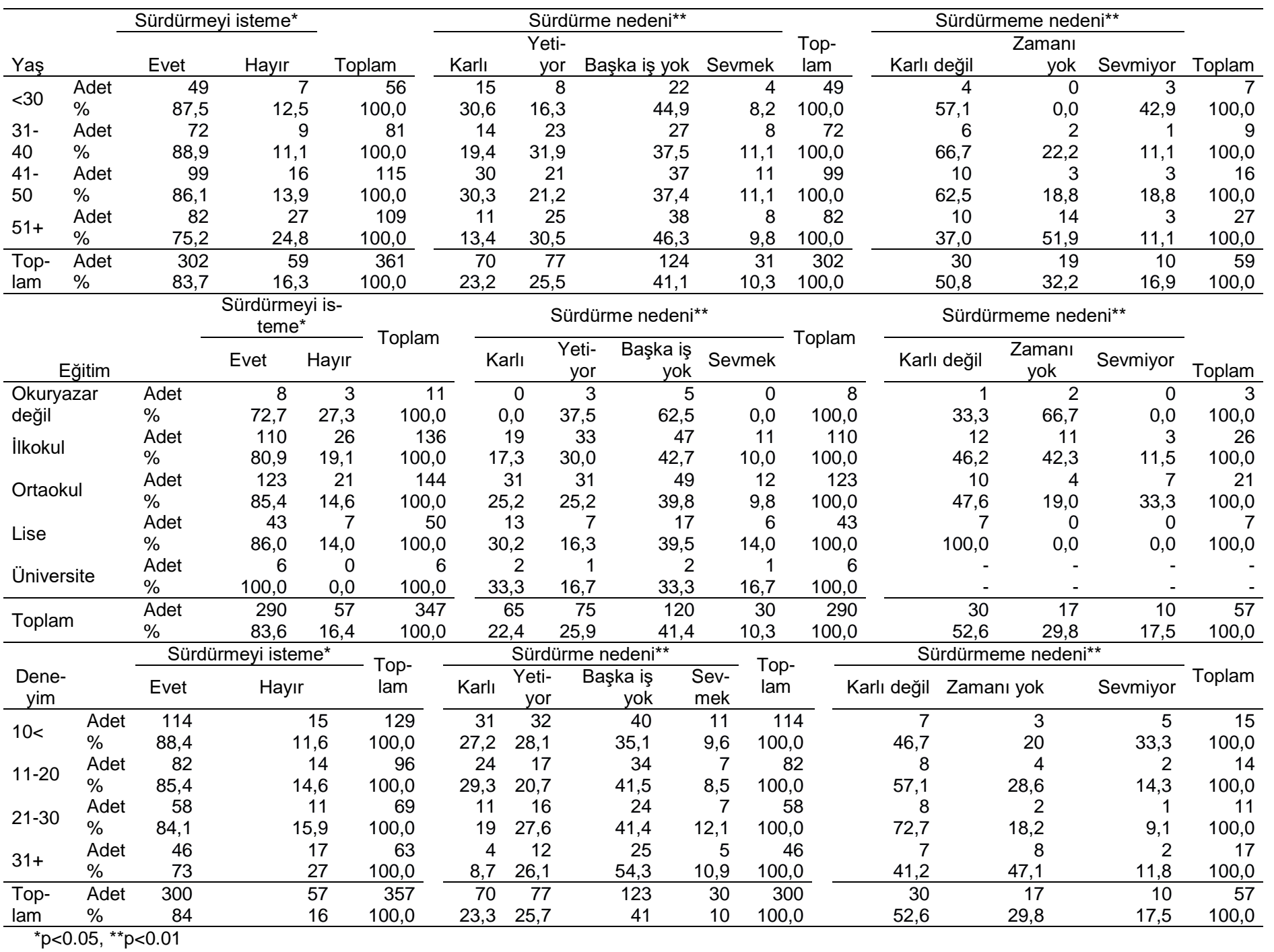

İşletmecilerin yaşı ile besiciliği sürdürme arasındaki ilişki önemli $(p<0.05)$ bulunmuştur. Buna göre, 30 yaş ve altındaki işletmecilerde besiciliği sürdürme oranı $\% 87,5$ iken, yaş ilerledikçe bu oranın düştüğü ve yaşı $51+$ olan işletmecilerde bu oran \% 75,2 olarak belirlenmiştir. Bu iki grup işletmecilerde besiciliği sürdürme noktasında ortak neden, en fazla yapacak başka işleri olmaması iken, 30 yaş ve altındaki işletmecilerde besiciliğin karlı görülmesi ve yaşı $51+$ olan işletmecilerde ise elde edilen gelirin kendilerine yetmesi şeklindedir. Bu iki gruptan gençlerin, besiciliğe yeni başlamaları ve yaşılıarın ise geçime katkı olsun diye besiciliğe devam ettikleri ve genel olarak da başka iş yapmadıkları belirlenmiştir (Tablo 2 ).

Bu konuda yapılan benzer araştırmalarda, Han (2008)'ın Diyarbakır ili Ergani ilçesindeki besi işletmelerinde, işletmecilerin yaşlarının memnuniyet oranını önemli şekilde etkilediğini bildirmişlerdir. Buna göre, işletmecilerin yaşı arttıkça memnuniyet oranının azaldığı bildirilmektedir. Araştırmada, yaşları 18-30 olan işletmecilerde memnuniyet oranı \%73,7 iken, yaşları 50-80 olan işletmecilerde ise memnuniyet oranının \%37,1'e kadar düştüğü ve memnuniyetsizlik oranının \%62,9 ile en yüksek seviyeye çıktığı belirtilmiştir. Aynı araştırmada işletmecilerin memnun olma nedeni, hem genel olarak hem de farklı yaş grupları içerisinde yapacak başka işlerinin olmaması $(\% 74,1)$ en yüksek paya sahip olduğu belirtilmiştir. Bakır ve Kibar (2019a) yaşı 30'dan az olan işletmecilerin yaptıkları işten memnun olduklarını ve \%41,4'ünün karlı olduğu için işini sürdürmek istediklerini bildirmişlerdir. Aynı araştırmada yaş ile birlikte memnuniyet oranının düştüğü ve genç işletmecilerin yaşlılara göre hayvancılığı daha çok benimsediği bildirilmiştir. Bakır ve Kibar (2019b) Siirt ilinde besi işletmecilerinin yaşı arttıkça işini sürdürmek isteyenlerin oranının artıı̆ını bildirmişlerdir. 
Mevcut araştırma bulunan sonuçlar, Han (2008) ve Bakır ve Kibar (2019a)'ın sonuçları ile benzerlik gösterirken Bakır ve Kibar (2019b)'dan farklılık göstermektedir.

İşletmecilerin eğitim durumu ile besiciliği sürdürme arasındaki ilişki önemli $(p<0.05)$ bulunmuştur. Buna göre, besiciliği sürdürme oranı okuryazar olmayan işletmecilerde \%72,7 iken, eğitim düzeyi yükseldikçe besiciliği sürdürme oranı artmakta ve üniversite olan işletmecilerin tamamının besiciliğe devam edecekleri belirlenmiştir. Okuryazar olmayan işletmeciler besiciliği $\% 62,5$ oranında başka iş olmadığı için yaparken, eğitim seviyesi arttıkça bu oran \%33,3'e gerilemiştir. Buna göre, işletmecilerin eğitim seviyesi arttıkça besicilik zorunlu olarak yapılan iş olmaktan çıktığı ve besicilik hem bir meslek hem de geçim kaynağı olarak görülmektedir. Yine, okuryazar olmayan işletmeciler besiciliğin karlı olmadığını düşünürken, eğitim seviyesi arttıkça besiciliğin karlı bir faaliyet olduğunu düşünenlerin oranı ise artmaktadır. Hayvancılıktan memnun olan ve işi sürdürmek isteyen işletmecilerin eğitim düzeyi üniversite olanların dışındakilerin besiciliği sürdürme nedenlerinin daha çok başka işlerinin olmamasından kaynaklandığı belirlenmiştir. Ancak eğitim düzeyi üniversite olanlarda ise başka işlerinin olmamasının $(\% 33,3)$ yanında işletmecilerin $\% 33,3$ 'ünün yaptıkları işi karlı bulması dikkat çekici bulunmuştur (Tablo 2). Ayrıca, hayvancılıktan memnun olmayan ancak bu faaliyeti sürdürmek isteyen işletmecilerin tamamının, yapacak başka işlerinin olmaması dikkat çekici bulunmuştur. Han (2008)'nın yaptığı çalışmada okuryazarlık ile başlayan eğitim seviyesi arttıkça işletmecilerin memnuniyet oranının arttığını bildirilmektedir. Ancak, okuryazar olmayan işletmecilerin memnuniyet oranının $(\% 51,5)$ sadece okuryazar olan işletmecilerin memnuniyet oranından $(\% 33,3)$ daha yüksek olduğu bildirilmiştir. Köseman ve Şeker (2016) Malatya ilindeki sığırcılık işletmelerinde, işletmecilerin \%66,4'ünün eğitim durumunun lise ve üniversite düzeyinde olduğunu ve işletmecilerin \%76,8'inin yaptıkları işten memnun olduklarını bildirmişlerdir. Bakır ve Kibar (2019b) Siirt ilinde besi işletmecilerinin eğitim seviyesi ile memnuniyet arasında pozitif ilişki varken sürdürme arasında negatif bir ilişkinin olduğunu bildirmişlerdir. Bakır ve Kibar (2019a) Muş ilindeki süt işletmecilerinin eğitim seviyesinin işi sürdürme üzerine önemli derecede etki ettiğini bildirmişlerdir ( $P$ $<0.01)$. Bu araştırma sonuçları ile diğer araştırmacıların bildirdiği sonuçlar benzer bulunmuştur.

Hayvancılık yapılan süre (deneyim) ile besiciliği sürdürme ve sürdürmeme nedenleri arasında önemli $(p<0.05, p<0.01)$ ilişki bulunmuştur. Buna göre, deneyimi $10 \leq$ yıl ve daha az olan işletmecilerin besiciliği sürdürme oranı $\% 88,4$ iken, deneyim süresi arttıkça besiciliği sürdürme oranı düşmektedir. Deneyim süresi $31+$ yıl olan işletmecilerde besiciliği sürdürme oranı $\% 73$ olarak bulunmuştur. $\mathrm{Bu}$ işletmecilerin yaşlı ve besiciliği ticari amaçlı olarak değil de, geçime katkı amacıyla yapanlar olduğu düşünülmektedir. Ayrıca, besiciliğin karlı olduğunu düşünen işletmeciler arasında en düşük oran, bu gruptaki işletmeciler arasında bulunmuştur. Besicilikten memnun olan işletmecilerin deneyimleri arttıkça, sürdürme oranları düşmektedir. Ancak, sürdürme oranlarının düşmesine paralel olarak, besiciliği sürdürme nedeni olarak başka iş yok diyenlerin oranı da artmaktadır. Ayrıca, deneyimi fazla olan yaşlı yetiştiricilerin besiciliği sürdürmeme nedenleri arasında besiciliğe zaman ayıramama önemli bir oranda $(\% 47,1)$ bulunmuştur (Tablo 2 ). Bu duruma göre, deneyimi fazla olan yaşlı işletmecilerin yapacak başka işleri olmadığı için zorunlu olarak besicilik yaptıkları belirlenmiştir.

Han (2008) deneyim süresi ile memnuniyet arasında doğru orantı olduğunu ve deneyim süresi arttıkça memnuniyet oranının da arttığını bildirmişlerdir. Fakat 8-13 yıl arasında deneyime sahip olan işletmecilerin memnuniyetinin $(\% 47,6)$ diğer tüm gruplardan daha düşük olduğunu bildirmiştir. Köseman ve Şeker (2016) ise, işletmecilerin \%81, 1 'inin 11 yıldan fazla deneyim süresine sahip olduklarını ve \%76,8'inin yaptıkları işten memnun olduklarını bildirmişlerdir. Bakır ve Kibar (2019a) yaş artıkça işletmecilerin sığırcılığı sürdürme oranının azaldığını, Bakır ve Kibar (2019b) ise yaş ile sürdürme oranının arttığını bildirmişlerdir.

Yapılan araştırmada, işletme tipi ve hayvan sayıları ile besiciliğin sürdürülmesi arasındaki ilişki Tablo 3'te sunulmuştur.

Kombine tipi işletmelerin $\% 77,1^{\prime} i$ besiciliği sürdürmek isterken, bu oran besi tipi işletmelerde \%84,2'ye yükselmektedir. Besi tipi işletmelerin besi sonunda hayvanlarını eder fiyata karlı sattıkları sürece besiciliği sürdürme kararlılığında oldukları belirlenmiştir. Kombine tipi işletmelerde besiciliği sürdürme nedeni olarak $\% 64,9$ oranıyla başka işin olmaması dikkat çekici olarak bulunmuştur (Tablo 3). Bakır ve Kibar (2019a)'ın Muş ilinde yaptıkları araştırmada, kombine tipi işletmesi olan işletmecilerin hayvancılıktan memnun olma nedenlerini başka iş yok (\%32), bana yetiyor (\%23) ve karlı (\%20) şeklinde bildirmişlerdir. Bu araştırmada bulunan sonuçlar ile Bakır ve Kibar (2019a)'ın bildirdiği sonuçlar arasında benzerlik bulunmaktadır.

İşletmelerde besiciliği sürdürme oranı hayvan sayısı $5 \leq$ olan işletmelerde $\% 78,4$ iken, bu oran hayvan sayısı $61+$ olan işletmelerde \%89,5'e yükselmiştir. İşletmelerdeki hayvan sayısı arttıkça işletmecilerin besiciliği sürdürme oranı da artmaktadır. İşletmelerde bulunan hayvan sayısı ile besiciliği sürdürme nedenleri arasındaki ilişki 
önemli $(p<0.05)$ bulunmuştur. Hayvan sayısı arttıkça işletmelerin kapasitesi ve imkânlarının da arttığı göz önüne alındığında besiciliği karlı olduğu için sürdüren işletmelerin sayısı da doğrusal olarak artmaktadır. Ayrıca, hayvancılığı başka iş olmadığı için yapan işletmecilerin oranı hayvan sayısı az olan işletmelerde $\% 50$ civarında iken, hayvan sayısı çok olan işletmelerde bu oran \%19,6 olarak belirlenmiştir (Tablo 3). Sonuç olarak, hayvan sayısı az olan işletmelerin besiciliği ev intiyacını karşılamak ve az da olsa geçime katkı amacıyla yaptıkları, hayvan sayısı çok olan işletmeler ise ki bunlar entansif şartlarda veya yakın işletmecilik yapanlar, besiciliği ticari amaçla yapan ve kar elde ettikleri için sürdüren işletmelerdir.

Bakır ve Kibar (2019b) Siirt ilinde yaptıkları araştırmada, hayvan sayısı az olan besi işletmecilerinin memnuniyet oranlarının hayvan sayısı daha fazla olan işletmecilere oranla daha yüksek olduğunu bildirmişlerdir. İşletmelerde bu durumun işletmecilerin hayvancılığı ek gelir elde etmek ve geçime katkı yapmak ya da hobi olarak yapmalarından kaynaklı olduğunu bildirmişlerdir. Ayrıca, hayvan sayısı arttıkça işletmecilerin besiciliği ticari olarak ve daha profesyonel olarak yaptıkları göz önüne alındığında, işletmecilerin besiciliği sürdürme nedeni olarak, besiciliği karlı olduğu için yaptıklarını bildirmişlerdir.

Yapılan araştırmada, besicilik yapma nedeni ile besiciliğin sürdürülmesi arasındaki ilişki Tablo 4'te sunulmuştur.

Besiciliği baba mesleği ve severek yapan işletmeciler \%82-83 oranında besiciliği sürdürmek isterken, başka iş olmadığı için besicilik yapanlarda bu oran bir miktar düşerek \%77 olarak bulunmuştur. Buna göre, besiciliği baba mesleği ve severek yapanların, başka iş olmadığı için zorunlu olarak yapanlardan besicilikten daha memnun oldukları ve besiciliği sürdürme noktasında da daha hevesli oldukları belirlenmiştir. Besiciliği baba mesleği olarak yapan işletmecilerin \%42,7'sinin besiciliği başka iş olmadığı için sürdürmeleri, bu işletmecilerin besicilikten çok memnun olmadıklarını düşündürmektedir. Ayrıca, bu işletmecilerin besiciliği benzer oranlarda karlı bulmaları ve elde edilen gelirin kendilerine yettiğini ifade etmeleri yukarıdaki verilen sonucu da desteklemektedir. Başka iş olmadığı için besicilik yapan işletmecilerin sadece $\% 13,4$ 'nün besiciliği karlı bulmaları ve $\% 22,4$ 'nün elde edilen gelirin kendilerine yettiğini ifade etmeleri, bu işletmecilerin besicilikten çok da memnun olmadıklarının diğer bir işareti olarak da görülebilir. Besiciliği başka iş olamadığı için yapan işletmecilerin \%52,2'nin yine başka iş olmadığı için besiciliği sürdürmeleri anlamlı bulunmuştur (Tablo 4). Bu işletmecilerin besiciliği başka iş olmadığı için zorunluluktan yaptıkları anlamına gelmektedir. Öztürk (2009) Mardin ilindeki süt sığırı işletmecilerinin \%83.87'sinin yaptıkları işten memnun olduğunu ve araştırıcı bu oranın artırımasının işletmecilerin hayvancılığı sevmelerine bağlı olduğunu bildirmiştir. Tugay ve Bakır (2009) Giresun yöresindeki işletmecilerin \%96'sının yaptıkları işten memnun olduklarını ve memnuniyetin ev ihtiyacını karşılama $(\% 14)$, geçime katkı $(\% 9,8)$ ve tek geçim kaynağı $(\% 73,7)$ faktörlerinden kaynaklandığını bildirmişlerdir. Mevcut araştırma bulguları, Öztürk (2009) ve Tugay ve Bakır (2009)'ın sonuçları ile uyum içerisindedir. 
Muş İlindeki Besi İşletmelerinde Sürdürülebilir Üretim ve Bunu Etkileyen Faktörler

Tablo 3. İşletme tipi ve hayvan sayıları ile besiciliğin sürdürülmesi arasındaki ilişki

\begin{tabular}{|c|c|c|c|c|c|c|c|c|c|c|c|c|c|}
\hline \multirow{2}{*}{\multicolumn{2}{|c|}{ İşletme tipi }} & \multicolumn{2}{|c|}{$\begin{array}{l}\text { Sürdürmeyi } \\
\text { isteme* }\end{array}$} & \multirow{2}{*}{$\begin{array}{l}\text { Top- } \\
\text { lam }\end{array}$} & \multicolumn{4}{|c|}{ Sürdürme nedeni** } & \multirow{2}{*}{ Toplam } & \multicolumn{3}{|c|}{ Sürdürmeme nedeni** } & \multirow[b]{2}{*}{ Toplam } \\
\hline & & Evet & Hayır & & Karlı & Yetiyor & $\begin{array}{l}\text { Başka } \\
\text { iş yok }\end{array}$ & Sevmek & & $\begin{array}{r}\text { Karlı de- } \\
\text { ğil }\end{array}$ & Zamanı yok & Sevmiyor & \\
\hline \multirow{2}{*}{$\begin{array}{l}\text { Kom- } \\
\text { bine }\end{array}$} & Adet & 37 & 11 & 48 & 5 & 5 & 24 & 3 & 37 & 7 & 4 & 0 & 11 \\
\hline & $\%$ & 77,1 & 22,9 & 100,0 & 13,5 & 13,5 & 64,9 & 8,1 & 100,0 & 63,6 & 36,4 & 0,0 & 100,0 \\
\hline \multirow{2}{*}{ Besi } & Adet & 246 & 46 & 292 & 58 & 70 & 92 & 26 & 246 & 23 & 13 & 10 & 46 \\
\hline & $\%$ & 84,2 & 15,8 & 100,0 & 23,6 & 28,5 & 37,4 & 10,6 & 100,0 & 50,0 & 28,3 & 21,7 & 100,0 \\
\hline \multirow{3}{*}{$\begin{array}{l}\text { Top- } \\
\text { lam }\end{array}$} & Adet & 283 & 57 & 340 & 63 & 75 & 116 & 29 & 283 & 30 & 17 & 10 & 57 \\
\hline & $\%$ & 83,2 & 16,8 & 100,0 & 22,3 & 26,5 & 41,0 & 10,2 & 100,0 & 52,6 & 29,8 & 17,5 & 100,0 \\
\hline & & \multicolumn{2}{|c|}{$\begin{array}{l}\text { Sürdürmeyi } \\
\text { isteme }\end{array}$} & & \multicolumn{4}{|c|}{ Sürdürme nedeni** } & & \multicolumn{3}{|c|}{ Sürdürmeme nedeni } & \\
\hline \multicolumn{2}{|c|}{$\begin{array}{l}\text { Hayvan sa- } \\
\text { yısı }\end{array}$} & Evet & Hayır & $\begin{array}{l}\text { Top- } \\
\text { lam }\end{array}$ & Karlı & Yetiyor & $\begin{array}{l}\text { Başka } \\
\text { iş yok }\end{array}$ & Sevmek & Toplam & $\begin{array}{r}\text { Karlı de- } \\
\text { ğil }\end{array}$ & $\begin{array}{r}\text { Zamanı } \\
\text { yok }\end{array}$ & Sevmiyor & Toplam \\
\hline \multirow[t]{2}{*}{$5<$} & Adet & 76 & 21 & 97 & 18 & 24 & 26 & 8 & 76 & 9 & 6 & 6 & 21 \\
\hline & $\%$ & 78,4 & 21,6 & 100,0 & 23,7 & 31,6 & 34,2 & 10,5 & 100,0 & 42,9 & 28,6 & 28,6 & 100,0 \\
\hline \multirow[t]{2}{*}{$6-20$} & Adet & 91 & 15 & 106 & 18 & 16 & 47 & 10 & 91 & 8 & 5 & 2 & 15 \\
\hline & $\%$ & 85,8 & 14,2 & 100,0 & 19,8 & 17,6 & 51,6 & 11,0 & 100,0 & 53,3 & 33,3 & 13,3 & 100,0 \\
\hline \multirow[t]{2}{*}{$21-40$} & Adet & 59 & 11 & 70 & 11 & 11 & 33 & 4 & 59 & 5 & 5 & 1 & 11 \\
\hline & $\%$ & 84,3 & 15,7 & 100,0 & 18,6 & 18,6 & 55,9 & 6,8 & 100,0 & 45,5 & 45,5 & 9,1 & 100,0 \\
\hline \multirow[t]{2}{*}{$41-60$} & Adet & 27 & 4 & 31 & 9 & 9 & 8 & 1 & 27 & 1 & 3 & 0 & 4 \\
\hline & $\%$ & 87,1 & 12,9 & 100,0 & 33,3 & 33,3 & 29,6 & 3,7 & 100,0 & 25,0 & 75,0 & 0,0 & 100,0 \\
\hline \multirow[t]{2}{*}{$61+$} & Adet & 51 & 6 & 57 & 14 & 20 & 10 & 7 & 51 & 1 & 3 & 1 & 6 \\
\hline & $\%$ & 89,5 & 10,5 & 100,0 & 27,5 & 39,2 & 19,6 & 13,7 & 100,0 & 16,6 & 50,0 & 16,7 & 100,0 \\
\hline \multirow{2}{*}{$\begin{array}{l}\text { Top- } \\
\text { lam }\end{array}$} & Adet & 304 & 57 & 361 & 70 & 80 & 124 & 30 & 304 & 24 & 23 & 10 & 57 \\
\hline & $\%$ & 84,2 & 15,8 & 100,0 & 23,0 & 26,3 & 40,8 & 9,9 & 100,0 & 42,1 & 40,4 & 17,5 & 100,0 \\
\hline
\end{tabular}

Tablo 4. Besicilik yapma nedeni ve eder fiyata satma ile besiciliğin sürdürülmesi arasındaki ilişki

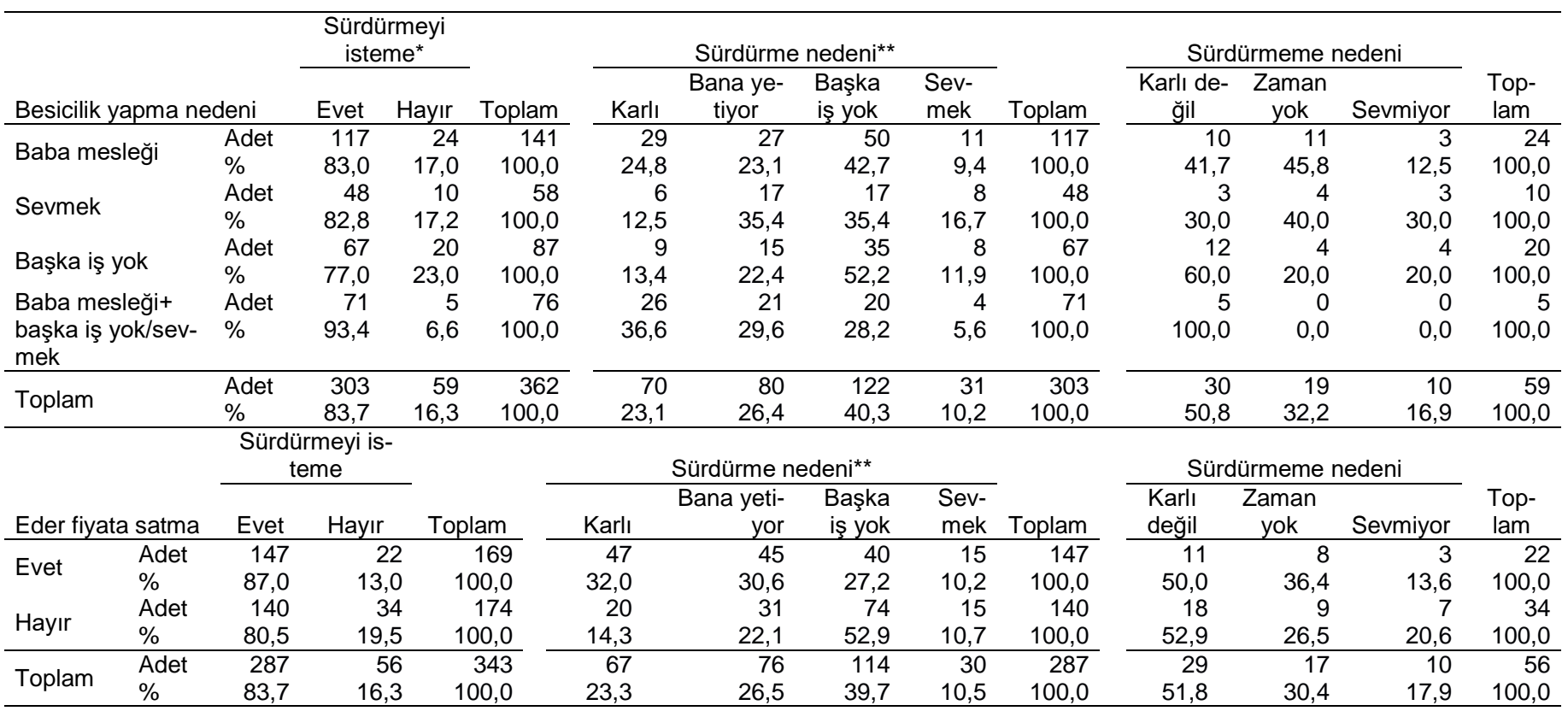


Besi sonunda hayvanlarını eder fiyata satan ve işi sürdürmek isteyen işletmecilerin (\%87) çoğunluğu sürdürme nedeni olarak yaptıkları işin karlı olduğunu (\%32), kendileri için yeterli olduğunu $(\% 30,6)$ ve işlerini sevdiklerini $(\% 27,2)$ bildirmişlerdir (Tablo 4). Ayrıca, besiciliği başka iş olmadığı için yapan işletmecilerin oranı sadece $\% 27,2$ olarak bulunmuştur. Bu durum, hayvanlarını eder fiyata satan işletmecilerin besicilikten memnun oldukları ve besiciliği de severek yaptıkları anlaşılmaktadır. Besiciliğin sürdürülebilir olmasına besi sonunda hayvanların pazarlanması ve fiyat politikasının memnun edici olması için gerekli tedbirlerin alınması gerekmektedir. Besi sonunda hayvanlarını hem eder fiyata satan hem de satamayan ve besiciliği de karlı olmadığını düşünerek sürdürmek istemeyen işletmecilerin önemli oranlarda bulunması dikkat çekici bulunmuştur. Bakır ve Kibar (2019b) Siirt ilinde hayvanlarını eder fiyata satan işletmecilerin \%89,7'sinin yaptıkları işi sürdürmek istediklerini bildirmişlerdir. Mevcut araştırma sonuçları ile Bakır ve Kibar (2019b)'ın sonuçları uyum içerisindedir.

Besicilikten memnun olan (\%92) işletmecilerin $\% 31,1$ 'inin besiciliği karlı buldukları ve \%24,7'sinin elde edilen geliri yeterli buldukları için sürdürmek istedikleri belirlenmiştir. Ancak, işletmecilerin \%32,9'unun da başka iş olmadığı için besiciliği sürdürmeleri, besiciliği zorunlu olarak yaptıklarının işareti olarak değerlendirilebilir. Besicilikten memnun olmayıp ancak besiciliği de sürdürmek isteyen $(\% 67,7)$ işletmecilerin besiciliği sürdürmelerine sebep olarak \%60,7 oranında başka işlerinin olmamasını bildirmeleri önemli bulunmuştur. İşletmecilerin hem besicilikten memnun olmamaları hem de besiciliği sürdürmeleri zorunluluktan kaynaklandığını düşündürmektedir. Insanların beslenmesinde hayvansal gıdanın temelini oluşturan besiciliğin sürdürülebilirliği bakımından, işletmecilerin besiciliği severek ve isteyerek yapmaları sağlanmalıdır. Diğer yandan, besicilikten memnun olan ancak besiciliği sürdürmek istemeyen işletmecilerin, besiciliği sürdürmeme nedeni olarak zamanlarının olmamasını bildirmemeleri, başka iş yaptıkları ve geçime katkı amaçlı yaptıklarını düşündürmektedir. Bunun yanında, hem besicilikten memnun olmayan hem de besiciliği sürdürmek istemeyen işletmecilerin \%75'i besiciliği karlı olarak görmedikleri belirlenmiştir. Kaygısız ve ark. (2008) Kahramanmaraş ilindeki işletmecilerin \%67'sinin sığırcılıktan memnun olduklarını bildirmişlerdir. Aynı araştırıcılar, işletmecilerin işi sürdürme nedenlerini ise sığırcılığın yörede tek geçim kaynağı olması, tarla ziraatından zarar edilen dönemde ek gelir sağlaması ve hiç olmazsa yılda bir kez alınan buzağının işletme bütçesine katkı sağlaması şeklinde bildirmişlerdir. Şeker ve ark. (2012) ise, Muş ilinde sığır işletmelerinde yaptıkları çalışmada işletmecilerin \%62,6'sının yaptıkları işten memnun olmadıklarını bildirmişlerdir. Aynı araştırıcılar işletmecilerin \%55,1'inin bu işi geçim kaynağı olarak ve \%33,9'unun geçime katkı olarak yaptıklarını bildirmişlerdir. Mevcut araştırma sonuçları ile Kaygısız ve ark. (2008) ve Şeker ve ark. (2012) sonuçları sığır işletmecilerinin işi sürdürme nedenleri bakımından benzerlik göstermektedir.

\section{SONUÇ}

Araştırma bulgularına göre işletmecilerin çoğunluğu besiciliği elde edilen gelirin kendilerine yetmesi ve karlı olduğunu düşündükleri için sürdürmek istemektedirler. Ayrıca; besiciliğin sürdürülebilirliği, işletmecilerin yaşı, eğitim durumu ve deneyimleri ile işletmede mevcut hayvan sayısı ve besi sonunda hayvanların eder fiyata satılması gibi faktörlerden etkilenmektedir. Ele alınan bu faktörlerden hayvanların eder fiyata satılabilmesi ise besiciliğin sürdürülmesinde diğer faktörlere göre daha etkili olduğu görülmektedir. Bu nedenle besi işletmecilerinin para kazandıkları sürece bu işi sürdürmek isteyecekleri düşünülmektedir. Sonuç olarak hayvancılığın gelişmesine etki eden olumsuzlukların giderilip, gelişmesi yönünde alınacak her karar ve yapılacak her uygulama Muş ilindeki besiciliğin sürdürülebilir olmasına katkı sağlayacaktır.

\section{KAYNAKLAR}

Anonim (2018). Hayvancılık İstatistikleri. Türkiye İstatistik Kurumu. https://biruni.tuik.gov.tr/hayvancilikapp/hayvancilik.zul (Erişim tarihi: 09.03.2018).

Bakır, G., Kibar, M. (2019a). Süt Sığırcılığı İşletmelerinin Memnuniyet ve Sürdürülebilirliğine Etkili Olan Faktörler: Muş İli Örneği. Turk J Agric Res 6(2): 123-135.

Bakır, G., Kibar, M. (2019b). Siirt İli Besi Sığırı İşletmelerinde Memnuniyet ve Sürdürülebilirliğin Belirlenmesi. International Erciyes Agriculture, Animal \& Food Sciences Conference, 24-27 April 2019, Kayseri, Turkey.

Bakır, G., Kibar, M. (2019c). Muş İlinde Bulunan Süt Sığırcılığı İşletmelerinin Bazı Yapısal Özelliklerinin Crostabb Analiziyle Belirlenmesi. Kahramanmaraş Sütçü İmam Üniversitesi Tarım ve Doğa Dergisi 22(4): 609-619.

Bakır, G., Kibar, M. (2020). Muş İli Besi Sığırcılığı İşletmelerinin Bazı Yapısal Özelliklerinin Belirlenmesi. Kahramanmaraş Sütçü Imam Üniversitesi Tarım ve Doğa Dergisi 23(6): 1687-1697.

Cochran, W.G. (1977). Sampling techniques (3rd Edition). John Wiley\&Sons. New York. https://www.academia.edu/29684662/Cochran_1977_Sampling_Techniques Third_Edition. pdf. (Erişim: 14.01.2019).

Düzgüneş, O., Kesici, T., Gürbüz, F. (1983). İstatistik Metodları I. A.Ü. Ziraat Fak. Yay. No:229.

Han, Y. (2008). Diyarbakır İli Ergani İlçesinde Besi Sığırcılığı Yapan İşletmelerin Genel Değerlendirilmesi. YYÜ Üniv. Fen Bilimleri Enstitüsü Zootekni Anabilim Dalı. Yüksek Lisans Tezi, Van.

Hockerts, K. (2001). Corporate Sustainability Management Towards Controlling Corporate Ecological and Social Sustainability. Sustainability at the Millennium: Globalization. 
Competitiveness and the Public Trust January 21-25. Ninth International Conference of Greening of Industry Network, Bangkok.

Kaygısız, A., Tümer, R., Orhan, H., Vanlı, Y. (2008). Kahramanmaraş bölgesi süt sığırcılık işletmelerinin yapısal özellikleri: 1. Yetiştirme uygulamaları. SDÜ. Ziraat Fakültesi Dergisi 3(2): 23-31.

Koçyiğit, R., Diler, A., Yanar, M., Güler, O., Aydın, R., Avcı, M. (2016). Süt sığırcılığı işletmelerinde hayvan sağlığı, veteriner sağlık hizmetleri ve yetiştirici memnuniyeti: Erzurum ili Hınıs ilçesi örneği. Türk Tarım ve Doğa Bilimleri Dergisi 3(1): 24-32.

Köseman, A., Şeker, İ. (2016). Malatya ilinde sığırcılık işletmelerinin mevcut durumu: I. Yapısal özellikler. Fırat Üniv. Sağlık Bilimleri Dergisi 30(1): 5-12.

Öztürk, N.N. (2009). Mardin ilindeki süt sığırcılığı işletmelerinin yapısal özellikleri. SÜ. Fen Bilimleri Enstitüsü, Zootekni ABD, Yüksek Lisans Tezi, 65s.

Pezikoğlu, F. (2012). Sürdürülebilir tarım ve kırsal kalkınma kavramı içinde tarım-turizm-kırsal alan ilişkisi ve sonuçları. Karamanoğlu Mehmet Bey Üniversitesi Sosyal ve Ekonomik Araştırmalar Dergisi 14(22): 83-92.
Russell, S., Haigh, N., Griffiths, A. (2007). Understanding Corporate Sustainability. Corporate Governance And Sustainability. Chapter 2.

Soyak, A., Soysal, M.I., Gürcan, E.K. (2007). Tekirdağ ilindeki süt sığırcılığı işletmelerinin yapısal özellikleri ve bu işletmelerdeki siyah alaca süt sığırlarının çeşitli morfolojik özellikleri üzerine bir araştırma. Tekirdağ Ziraat Fakültesi Dergisi 4(3): 297-305.

SPSS Inc., 1999. SPSS Categories. Version 10.0. Chicago.

Şeker, İ., Tasalı, H., Güler, H. (2012). Muş ilinde sığır yetiştiriciliği yapılan işletmelerin yapısal özellikleri. FÜ. Sağ. Bil. Vet. Dergisi 26(1): 9-16.

Tugay, A., Bakır, G. (2009). Giresun yöresindeki süt sığırcılığı işletmelerinin yapısal özellikleri. Atatürk Üniv. Ziraat Fakültesi Dergisi 40(1): 37-47.

Turhan, Ş. (2005). Tarımda sürdürülebilirlik ve organik tarım. Tarım Ekonomisi Dergisi 11(1): 13-24.

Yamane, T. (2006). Temel örnekleme yöntemleri. (Çeviri: Esin, A., Bakır, M.A., Aydın, C., Güzbüzsel, E.) Literatür Yayınları: 53, İstanbul, 411. 